\title{
RAGAM ARTEFAK DI SITUS-SITUS NEOLITIK SEPANJANG CI LANGLA BAGIAN HILIR, KABUPATEN TASIKMALAYA
}

\section{Variety Of Artefaks In Neolithic Sites All Through Ci Langla, in Tasikmalaya}

\author{
Nurul Laili ${ }^{1)}$ dan Anton Febrianto ${ }^{2)}$ \\ Balai Arkeologi Jawa Barat \\ Jalan Raya Cinunuk Km. 17, Cileunyi, Bandung \\ ${ }^{1)}$ E-mail: nurulkarangkajen@yahoo.com (Corresponding author) \\ ${ }^{2)}$ E-mail: antonboton@gmail.com
}

Naskah diterima: 9 Juni 2020 - Revisi terakhir: 27 September 2020

Disetujui terbit: 27 September 2020 - Tersedia secara online: 28 September 2020

\begin{abstract}
Neolithic sites in the Karangnunggal Region along Ci Langla, starting from upstream to downstream. This paper will reveal the variety of neolithic artifacts in Ci Langla downstream. Thus it will be known about the activities of human life supporting neolithics in the area. Research on the distribution patterns and influencing factors is expected to be able to provide clues about human behavior patterns in utilizing space. The method used in the cultural approach focuses on archeological material or direct observation of artifacts (artifact oriented analysis). The artifacts analyzed are related to the activities of the adze workshop.
\end{abstract}

Keywords: neolithic sites, variety, adze workshop

\begin{abstract}
Abstrak
Situs-situs neolitik di Kawasan Karangnunggal berada di sepanjang Ci Langla, mulai dari hulu hingga hilir. Ragam artefak di bagian hulu dan tengah Ci Langla mempunyai ragam artefak berupa beliung jadi, calon beliung, bahan gelang, serpih, tatal, dan bahan baku yang mengarah ke bentuk segi empat sebagai hasil dari proses pembuatan beliung dan gelang batu, sedangkan ragam artefak di bagian hilir belum diketahui. Tulisan ini akan mengungkap tentang ragam artefak neolitik di Ci Langla bagian hilir. Penelitian mengenai ragam artefak di Ci Langla bagian hilir akan dapat mengetahui aktivitas kehidupan manusia pendukung neolitik dalam memanfaatkan ruang. Metode yang digunakan pendekatan kebudayaan menitikberatkan pada materi arkeologi atau pengamatan langsung kepada artefak (artefact oriented analysis). Ragam artefak di situs-situs sepanjang aliran Ci Langla bagian hilir menunjukkan adanya aktivitas perbengkelan. Artefak tersebut berupa bahan baku, calon beliung, beliung jadi, bahan gelang, alat serpih, tatal berukuran kecil, sedang, dan besar.
\end{abstract}

Kata kunci: situs neolitik, ragam, bengkel beliung 


\section{PENDAHULUAN}

Kehidupan manusia pada masa prasejarah mengalami proses yang panjang, dari budaya tertua hingga sesudahnya, diawali dari corak budaya paleolitik, mesolitik/ preneolitik, neolitik, dan paleometalik. Salah satu budaya prasejarah, yaitu neolitik masih sangat terbatas informasinya di Indonesia. Neolitik merupakan tonggak revolusi perkembangan budaya di mana ditandai dengan penemuan-penemuan baru dan yang memiliki unsur-unsur peletak dasar budaya sekarang. Neolitik juga dapat diartikan sebagai perubahan mendasar pada cara hidup manusia, dari yang semula bergantung dari alam menjadi pengolah sumberdaya alam (Simanjuntak, 1992).

Penelitian untuk mengupas kehidupan neolitik di Indonesia telah dilakukan di beberapa situs di wilayah nusantara. Situs pemukiman neolitik teramati di Kalumpang dan Minanga Sipakko (Kabupaten Mamuju, Sulawesi Barat), Kendenglembu (Kabupaten Banyuwangi, Jawa Timur), Nanga Balang (Kabupaten Kapuas Hulu, Kalimantan Barat). Jejak pemukiman pada situs-situs tersebut berupa tembikar, alat-alat neolitik, dan tulangtulang binatang yang diperkirakan sisa makanan. Adapun bangunan tempat tinggal belum pernah ditemukan (Simanjuntak, 1992:124).

Jejak neolitik lainnya berupa situs bengkel. Jejak situs bengkel paling banyak diperoleh dan tersebar luas di Indonesia. Situs-situs bengkel diperoleh antara lain di Bungamas (Kabupaten Lahat, Sumatera Selatan), Karangnunggal (Kabupaten Tasikmalaya, Jawa Barat), Pasir Kuda (Bogor, Jawa Barat), Pegunungan Karangbolong (Kabupaten Kebumen, Jawa Tengah), Punung (Pacitan, Jawa Timur), dan Tipar Ponjen (Kabupaten Purbalingga, Jawa Tengah). Penelitian situs bengkel yang telah intensif dilakukan adalah di 19 situs perbengkelan Purbalingga dan ratusan situs neolitik di Punung, yaitu Bomoteleng. Hasil-hasil penelitian selama ini telah dapat memberikan penjelasan tentang aspek tingkah laku dan pertanggalan kapan perbengkelan di situssitus tersebut berlangsung (Simanjuntak, 1992: 124-125; Tanudirdjo, 1991: 50).

Kehidupan neolitik Jawa Barat belum terkuak secara optimal. Penelitian yang telah dilakukan di Jawa Barat masih sangat sedikit. Indikator pemukiman neolitik Jawa Barat belum diperoleh, kalau pun ada petunjuk adanya kehidupan neolitik umumnya berupa jejak adanya aktivitas bengkel. Situs perbengkelan di Jawa Barat yaitu di Situs Pasirgadung, Cineam (Kabupaten Tasikmalaya, Jawa Barat) (Laili, 2012: 113-122), Sukabumi, Kawasan Karangnunggal (Kabupaten Tasikmalaya, Jawa Barat) (Heekeren, 1972; Handini, 1999; Laili, 2014; Laili, 2015; Laili, 2016).

Potensi neolitik di Kawasan Karangnunggal pertama kali tercatat oleh H.R van Hekeeren (1972) berdasarkan temuan penduduk setempat. Temuan beliung di kawasan Karangnunggal menjadi salah satu dasar dari Hekeeren membagi beliung persegi di Indonesia ke dalam 8 tipe. Kedelapan tipe tersebut adalah (a) Beliung Persegi, (b) Belincung, (c) Beliung Bahu, (d) Beliung Tangga, (e) Beliung Perisai, (f) Beliung Atap, (g) Beliung Biola, dan (h) Beliung Kuku (Heekeren, 1972:160-164).

Berdasarkan hasil penelitian Balai Arkeologi Bandung tahun 1997 di Karangnunggal, Anton Ferdianto melakukan analisis tipo-teknologi dan pengklasifikasian artefak. Temuan yang diperoleh di Karangnunggal dapat diklasifikasikan sebagai serut, calon beliung, beliung bola, batu inti, dan serpih pakai (Ferdianto, 2013).

Penelitian Retno Handini di kawasan Karangnunggal menunjukkan adanya situs-situs neolitik yaitu Leuwitere, Madur, dan Parakanhonje. Temuan yang diperoleh 
didominasi oleh temuan tatal, beliung, dan calon beliung. Temuan yang diperoleh merupakan temuan lepas yang sudah kehilangan konteks temuan (Handini, 1999: 17-20).

Penelitian di kawasan Karangnunggal kembali dilakukan oleh Balai Arkeologi Bandung yang sekarang berubah menjadi Balai Arkeologi Jawa Barat pada tahun 2014 - 2016. Penelitian awalnya difokuskan pada DAS Ci Langla bagian hulu dan tengah hasilnya adalah penempatan situs berada di Daerah Aliran Sungai Ci langla termasuk anak sungainya. Penelitian tersebut mendapatkan 14 situs neolitik dengan lokasi penempatan berada di dua bagian sungai, yaitu (1) situs di aliran sungai utama yaitu Ci langla dan (2) situs di aliran anak sungai Ci langla, antara lain Ci lumping, Ci karaha, Ci sodong, dan Ciharus. Jumlah yang berada di aliran sungai utama sebanyak lima situs, sembilan lainnya menempati anak sungai dari Ci langla (Laili, 2014: 30-35). Jejak tinggalan arkeologi yang diperoleh di keempatbelas situs mengindikasikan bahwa aktivitas yang dilakukan oleh manusia pendukung mengarah pada aktivitas perbengkelan beliung. Tinggalan tersebut berupa beliung jadi, bahan baku yang mengarah ke bentuk segi empat, calon beliung, bahan gelang, serpih dan tatal sebagai hasil dari proses pembuatan beliung dan gelang batu. Hasil analisis teknologi menunjukkan bahwa di kedua situs pembuatan beliung dari tahap awal hingga proses jadi.

Penelitian pada Ci Langla bagian hilir juga terdapat situs situs neolitik. Tulisan ini akan menjawab permasalahan tentang ragam artefak neolitik apa saja di Ci Langla bagian hilir. Dengan demikian akan diketahui tentang aktivitas kehidupan manusia pendukung neolitik di daerah tersebut sehingga akan dapat memberi petunjuk tentang pola perilaku manusia dalam memanfaatkan ruang.

Tulisan ini menggunakan penalaran induktif. Penalaran ini bergerak dari kajian fakta-fakta atau gejala-gejala yang bersifat khusus untuk kemudian disimpulkan sebagai gejala yang bersifat umum atau generalisasi empiris. Seringkali dalam penelitian ini sudah terdapat teori-teori. Apabila dalam penelitian ini sudah terdapat teori-teori dan definisi operasional maka komponen-komponen tersebut merupakan pengarah dalam penelitian(Tanudirdjo, 1989: 34).

Pendekatan yang digunakan untuk menjawab permasalahan adalah kebudayaan materi (Said, Chaksana A.H dan Utomo, 2006: 5). Pendekatan kebudayaan menitikberatkan pada materi arkeologi atau pengamatan langsung kepada artefak (artefact oriented analysis). Telaah yang dilakukan adalah analisis alat batu berupa analisis bentuk, teknologi, analisis jejak pakai, dan konteks (Simanjuntak, 2008: 39-48).

Analisis morfologi dilakukan untuk mengidentifikasi terhadap bentuk dan ukuran artefak. Analisis teknologi ialah mengidentifikasi teknik pembuatan artefak berdasarkan bahan baku, pengolahan bahan, teknik pengerjaan sampai benda dihasilkan termasuk teknik menghias. Adapun analisis jejak pakai mengkhususkan pada pengamatan terhadap hal-hal yang menunjukkan sisa sisa penggunaan. Analisis ini bertujuan untuk mengidentifikasi apakah suatu artefak pernah digunakan atau tidak (Simanjuntak, 2008: 39-41). Analisis selanjutnya adalah analisis kontekstual, yaitu untuk mengetahui hubungan artefak dengan temuan serta baik artefak, ekofak, fitur, dan ipsefak. Dalam melakukan analisis ini perlu diperhatikan transformasi baik budaya maupun bukan budaya (Simanjuntak, 2008: 40).

\section{HASIL DAN PEMBAHASAN}

Situs-situs neolitik yang berada di daerah hilir Ci Langla berjumlah 13 situs (gambar 
1). Bagian hilir Ci Langla berada di daerah Bantarkalong terutama di Desa Hegarwangi dan Desa Simpang. Secara admininstratif berada di wilayah Kecamatan Bantarkalong. Wilayah ini mempunyai ketinggian tempat rata-rata 253 meter di atas permukaan air laut. Jejak arkeologis yang diperoleh di daerah hilir Ci Langla berada di tiga desa, yaitu di Desa Parakanhonje, Desa Hegarwangi, dan Desa Simpang.

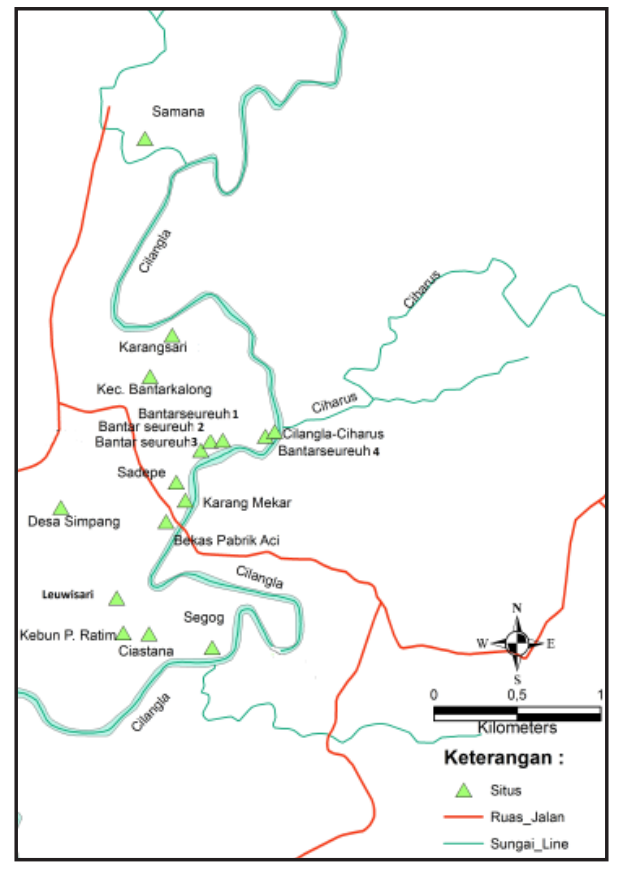

Gambar 1. Sebaran Situs Neolitik Ci Langla Hilir.

Tabel 1. Artefak Yang Diperoleh di Setiap Sïtus Neolitik Ci Langla bagian hilir

\begin{tabular}{|c|c|c|c|c|c|}
\hline $\mathrm{Ne}$ & Situs & Koordinat & Jenis Temun & Bahas & Jumlah \\
\hline \multirow[t]{3}{*}{1} & Samana & $07364141 " \mathrm{LS}$ & Bahe & RijungChri & $\mathbb{1}$ \\
\hline & & $1080634.77^{H}$ ВT & Sepih Gaky & Kursa, rijug & 5 \\
\hline & & & And Swupper & Rijand & $\mathbb{1}$ \\
\hline \multirow[t]{6}{*}{2} & Karangsari & 073709.71 LS & Bahas & Kursa dan rijang & 2 \\
\hline & & $1080640.06^{4}$ & Serpih ollaky & Jasper, kuars, & 41 \\
\hline & & $\mathrm{BT}$ & & rijug & \\
\hline & & & Tatal (deblige) & Karsa dan rijang & $s$ \\
\hline & & & Calon beliung (Broken & Rijand & 1 \\
\hline & & & PeAdz) & & \\
\hline \multirow[t]{3}{*}{3} & Bantarseureuh 1 & $6 T^{2} 37^{\prime} 29.43^{H} \mathrm{LS}$ & Serpih & Kürsa, rijang & 3 \\
\hline & & 1080648.17 & Tatal & Jasper & 1 \\
\hline & & BT & & & \\
\hline \multirow[t]{3}{*}{4} & Buntarsewruh 2 & $6 T^{2} 37^{\prime} 30.34^{H} \mathrm{LS}$ & Beliung Persegi & Rijang & II \\
\hline & & $1050647.48^{4}$ & & & \\
\hline & & BI & & & \\
\hline
\end{tabular}




\begin{tabular}{|c|c|c|c|c|c|}
\hline & & & Calon Gelang & Rijang & 1 \\
\hline & & & Bahe & Rijang & 4 \\
\hline & & & Sepih & Kusa, rijang & 10 \\
\hline & & & Tatal & Jasper, Kursa & 4 \\
\hline & & & Serut Samping & Rijang & 1 \\
\hline 5 & Bantarseureuh 3 & $\sigma^{\circ} 37^{\prime} 32.12^{4} \mathrm{LS}$ & Bahe & Kursa & 1 \\
\hline & & $1080645.63^{4}$ & Serpih & Rijang Kuzra & 5 \\
\hline & & $\mathrm{BT}$ & Senut & Kuarsa & 1 \\
\hline 6 & Bantarseureuh 4 & $\sigma T^{\prime} 377^{\prime} 30.21^{\prime \prime} \mathrm{LS}$ & Bahen & Jasper & 2 \\
\hline & & $1080649.88^{4}$ & Serpih & Rijang, Kuarsa & 5 \\
\hline & & $\mathrm{BT}$ & Tatal & Kwarsa & 1 \\
\hline & & & Calon buliung & Jasper & 1 \\
\hline 7 & Sadepe & $\sigma^{2} 37^{\prime} 38.38^{\prime \prime}$ LS & Bahe & Kuarsa dan rijang & 2 \\
\hline & & 1080640.87 & Serpih oldki & Kursa dan rijang & 31 \\
\hline & & BT & Tatul (detirge) & Kuarsa & 3 \\
\hline & & & $\begin{array}{l}\text { Calon beliung (woken } \\
\text { Piddre) }\end{array}$ & Kursa & 1 \\
\hline$s$ & Karmgmekar & $\sigma^{\infty} 37^{\prime} 41.89^{\mu}$ LS & Serpih $\partial d k \mid$ & Kursa, jasper, & $s$ \\
\hline & & $\begin{array}{l}1080698.89^{4} \\
\text { BT }\end{array}$ & Tatal (Webruge) & $\begin{array}{l}\text { Kursa, rijang. } \\
\text { jusper }\end{array}$ & 3 \\
\hline 10 & Leuwiari & $\begin{array}{l}07^{\circ} \text { is' } 00.91^{H} \mathrm{LS} \\
10 \mathrm{cot} 29.31^{H}\end{array}$ & Serpih olde) & $\begin{array}{l}\text { Kuarsa, rijang } \\
\text { jasper }\end{array}$ & 19 \\
\hline & & $\mathrm{BT}$ & & & \\
\hline 11 & Kebua Ratim & $\sigma^{2} 3 \mathrm{~s}^{\prime} 07.72^{\mathrm{H}} \mathrm{LS}$ & Bahe & Kuarsa & i \\
\hline & & $1050630.36^{4}$ & Serpih olde) & Rijang & 1 \\
\hline & & BT & $\begin{array}{l}\text { Calon gelang ( } w \text {. } \\
\text { shone broceled }\end{array}$ & Kursa & I \\
\hline & & & $\begin{array}{l}\text { Calon beliung (owe } \\
\text { shane adta) }\end{array}$ & Rijang & 3 \\
\hline 12 & Ciastana & $\mathrm{ot}^{\circ} \mathrm{3s}$ ' $07.87^{\prime} \mathrm{LS}$ & Przmen Calon & Kusara & 1 \\
\hline & & $1080635.56^{4}$ & Beliung & & \\
\hline & & $\mathrm{BT}$ & & & \\
\hline & & & Serpih olde) & Kuarsa, rijang & 4 \\
\hline & & & Muln noth Scruppy & Rijung & 1 \\
\hline 13 & Segog & $0 T^{\circ} 3 s^{\prime} 10.59^{\prime \prime} \mathrm{LS}$ & Bahabatu intivone & Japer & 1 \\
\hline & & $1080647.84^{4}$ & & & \\
\hline & & $\mathrm{BT}$ & & & \\
\hline & & & Serpih olde) & Jasper, rijang & 5 \\
\hline & & & Tatal (debirage) & Rijung & $\mathbb{1}$ \\
\hline
\end{tabular}


Tinggalan arkeologis yang diperoleh adalah beberapa batuan yang dikategorikan sebagai bahan baku, calon beliung, beliung jadi, bahan gelang, alat serpih, tatal berukuran kecil, sedang, dan besar. Keseluruhan temuan di situs ini dikelompokkan menjadi bahan baku (raw material) dan artefak yang dihasilkan dan buangan (tool manufactured and debitage). Secara rinci, artefak yang diperoleh di setiap situs tertera pada tabel 1.

\section{Bahan baku}

Bahan baku yang dipergunakan secara umum rijang, jasper, dan kuarsa. Situs-situs di kawasan Simpang yang terdapat temuan bahan baku, yaitu situs Samana, Karangsari, Bantarseureuh 2, Bantarseureuh 3, Bantarseureuh 4, Sadepe, Kebun Pak Ratim, dan Segog.

\section{Produk dan Limbah}

Produk atau hasil artefak yang dihasilkan melalui beberapa proses yaitu tahap pembentukan, tahap pengerjaan kedua kali, dan tahap pengerjaan akhir, kondisi ini memunculkan istilah calon beliung dan beliung jadi. Kegiatan dalam setiap tahapan mengalami proses reduksi atau pengurangan bahan, hasil pengurangan itulah bisa berupa tatal atau serpih.

\section{Calon Beliung}

Tahap pertama pembentukan beliung persegi adalah tahap pengerjaan bahan baku menjadi calon beliung yang dilakukan melalui pemangkasan awal. Dari seluruh calon beliung yang diperoleh, terlihat adanya pembentukan calon beliung kasar melalui pemangkasan primer secara langsung (direct percussion), sedangkan tingkat pengerjaan kedua adalah penghalusan calon beliung kasar, melalui pemangkaan sekunder. Kadangkadang usaha penggosokan sudah pula dilakukan pada kategori temuan, tetapi belum menyeluruh.

Pada tahap pertama dilakukan pemangkasan primer secara datar melebar (flattened chipping). Arah pangkasan dilakukan dari berbagai arah dengan maksud untuk menciptakan bentuk dasar persegi. Pangkasan tersebut umumnya menghasilkan bidang-bidang datar dengan meninggalkan bulbus-bulbus negatif berukuran lebar lebih dari $2 \mathrm{~cm}$. Pembentukan bidang sisi dilakukan dengan pemangkasan memanjang yang dikombinasikan dengan pemangkasan vertikal. Kadang-kadang masih tertinggal sedikit kulit batu (cortex) pada salah satu bidang. Tahapan ini menghasilkan artefak yang disebut dengan calon beliung tahap pertama.

Proses selanjutnya menghasilkan calon beliung tahap kedua yaitu usaha penghalusan permukaan melalui pengerjaaan kedua kali (secondary retouched). Pada umumnya pemangkasan ini hanya dilakukan di bagian pinggir saja dengan arah pangkasan dari pinggir ke tengah. Hal ini diketahui berdasarkan bulbus-bulbus negatif berukuran kurang dari $2 \mathrm{~cm}$. Ukuran bulbus negatif tersebut di satu pihak dan tatal-tatal batu kecil dengan dataran pukul yang sangat sempit di lain pihak, maka diduga pemangkasan dalam tahap ini dilakukan dengan memakai alat pembuat (fabricator), dalam arti pemangkasan tidak langsung (indirect percussion). Pemangkasan pada peertemuan bidang-bidang mebentuk pinggiran yang berliku-liku (zig-zag). Temuan memperlihatkan pengerjaan kedua kali yang teratur hingga menghasilkan calon beliung yang bagus. 
Pembuatan bagian tajaman dapat dilakukan dalam tahap pembentukan atau tahap pengerjaan kedua kali dengan jalan memangkas salah satu ujungnya (calon tajaman) ke arah hulu pada salah satu bidang calon beliung. Pemangkasan ini akan menghasilkan tajaman berlereng sepihak (unibevelled) yang merupakan ciri utama beliung. Setelah pemangkasan biasanya diikuti dengan penggososkan lereng tajaman untuk menciptakan permukaan yang halus. Penggosokan dapat dilakukan dengan batuan berbutir kasar, seperti misalnya batu pasir. Untuk mempercepat proses dibantu dengan pasir dan air sebagai materi abrasi (Bordaz, 1970: 99). Penggosokan dilakukan terhadap seluruh permukaan calon beliung, kecuali bagian hulu. Bagian ini biasanya dibiarkan kasar dan kalaupun digosok tingkatannya tidak seintensif permukaan lainnya sepert tampak pada bulbus-bulbus negatif yang masih menghiasinya. Kegiatan penggosokan terhadap permukaan biasanya diikuti oleh pengupaman (polishing) dengan maksud untuk membuat beliung tampak lebih indah dan berkilat. Pengupaman dapat dilakukan dengan alat semacam kulit atau bubuk yang digosokkan di permukaannya (Oakley, 1972: $33)$.

\section{Beliung jadi}

Beliung merupakan hasil proses pengerjaan tingkat lanjut terhadap calon beliung dengan jalan penggosokan dan pengupaman yang dicirikan adanya tajaman yang sempurna meski bagian lainnya belum sempurna. Atribut kuat beliung jadi adalah ketika suatu artefak menunjukkan salah satu atau keseluruhan ciri yaitu terdapatnya bekas pakai pada tajaman; tajaman sudah berbentuk sempurna, dan atau sudah diupam atau digosok secara sempurna (Gambar 2).

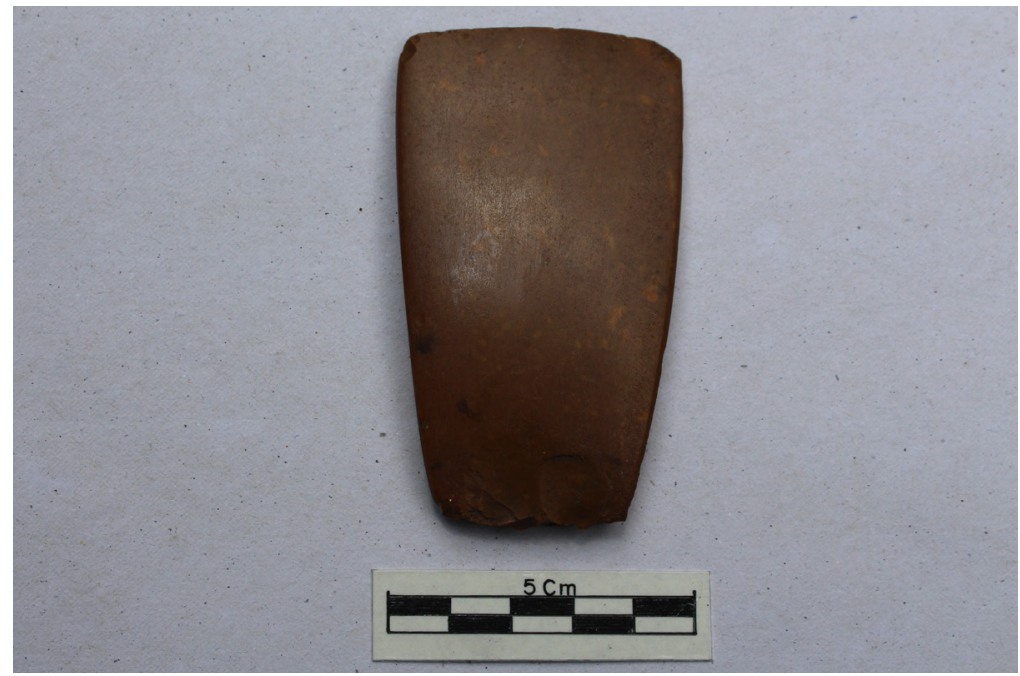

Gambar 2. Beliung jadi temuan di Situs Leuwisari (Sumber: Dokumen Balai Arkeologi Jawa Barat, 2016).

\section{Bahan Gelang}

Artefak bahan gelang merupakan bagian dari tahapan pengerjaan pertaman setelah persiapan dalam tahap pembuatan gelang. Bahan gelang berbentuk bundar dengan sisi permukaan datar dan sisi lingkaran membulat datar (Gambar 3). 


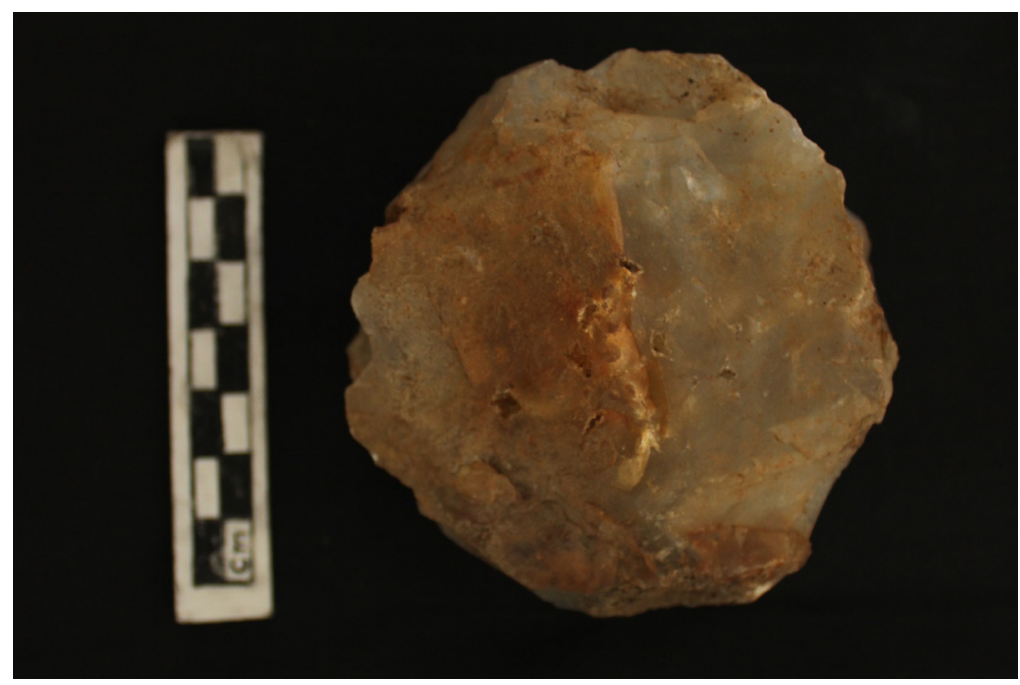

Gambar 3. Bahan gelang temuan di Situs Bantarseureuh 2 (Sumber: Dokumen Balai Arkeologi Jawa Barat, 2016).

\section{Tatal Batu dan Serpih}

Hasil penelitian yang dilakukan menunjukkan temuan tatal dan serpih merupakan temuan dalam jumlah terbanyak. Jenis batuan tatal dan serpih yang terbanyak adalah batuan kalsedon berwarna kuning keputihan. Keberadaan banyak tatal dan serpih mengindikasikan bahwa situs ini merupakan tempat perbengkelan.

Tatal adalah hasil reduksi dalam pembuatan beliung dan dihasilkan dari proses pembuatan beliung yang tidak disengaja. Hal ini dapat dilihat pada hampir keseluruhan tatal yang ditemukan yang tidak mempunyai ciri-ciri (atribut) yang dimiliki oleh serpih, seperti bekas pukul, dataran pukul, gelombang pukul (ripples), bulbus (bulb of percussion) yang mengindikasikan proses pembuatan alat batu pada umumnya.

Hasil reduksi ketika proses pembuatan beliung yang dihasilkan dari bahan baku beliung yang dilepaskan melalui penyerpihan.Oleh karena itu, ciri (atribut) yang dimilikinya tidak jauh berbeda dengan serpih yang digunakan sebagai alat, yaitu bekas pukul, dataran pukul, bulbus (bulb of percussion), dan gelombang pukul (ripples). Perbedaan yang paling mendasar adalah tidak adanya tajaman yang diperoleh melalui peretusan ataupun jejak pakai berupa striasi atau luka pakai.

Tatal hasil penelitian dapat dikelompokkan menjadi tiga kategori, yaitu tatal berukuran besar, sedang, dan kecil. Tatal berukuran besar dengan panjang bulbus negatif lebih dari $4 \mathrm{~cm}$. Tatal berukuran sedang dengan panjang bulbus negatif antara $2-4 \mathrm{~cm}$. Tatal berukuran kecil dengan panjang bulbus negatif kurang dari $2 \mathrm{~cm}$.

Besar kecilnya tatal berkait dengan poses pembuatan gelang batu dan beliung. Tatal yang berukuran lebih dari $2 \mathrm{~cm}$ berasal dari pengerjaan awal yaitu tahap pembentukan seebagai akibat dari teknik pukul langsung pada batu intinya. Adapun tatal berukuran kurang dari $2 \mathrm{~cm}$ sisa dari pengerjaan kedua yang biasanya dilakukan pemangkasan ringan dengan teknik pemukulan tidak langsung (gambar 4). 

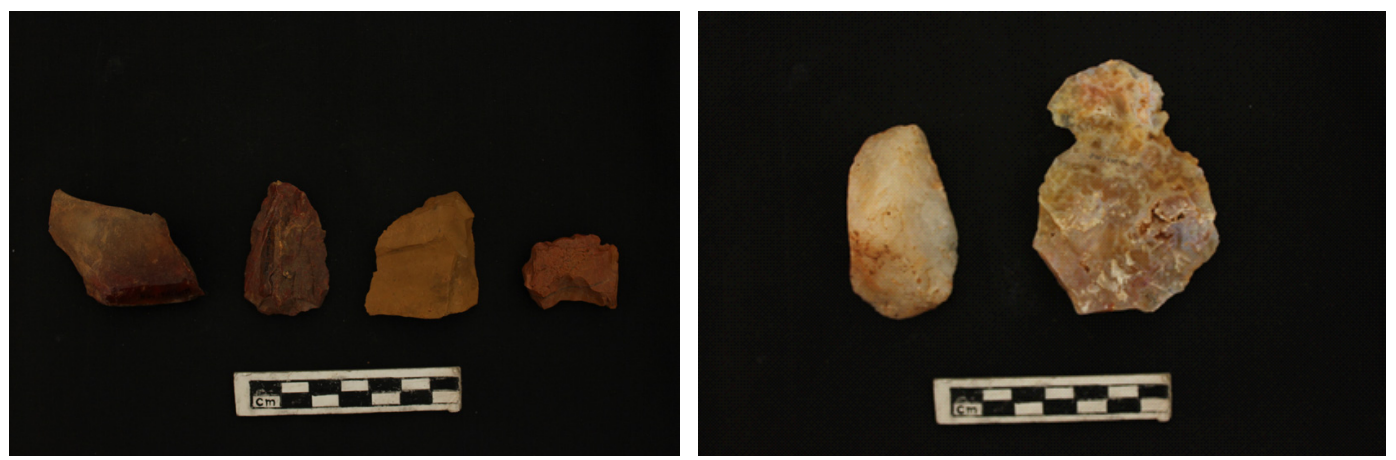

Gambar 4. Temuan Serpih di Situs Karangmekar dan Bantarsereuh 4 (Sumber: Dokumen Balai Arkeologi Jawa Barat, 2016).

Berdasarkan temuan di ketigabelas situs sepanjang Ci Langla hilir merupakan situs bengkel beliung. Kriteria situs bengkel sebagai berikut.(1) Artefak yang dihasilkan dari aktivitas perbengkelan. Artefak tersebut, adalah calon beliung, beliung, bahan gelang, sisa bahan gelang, dan gelang; (2) Sisa pengerjaan dari aktivitas perbengkelan. Temuan tersebut biasanya berupa serpih dan tatal batu; (3) Gabungan dari nomor (1) dan nomor (2).

Situs yang terdapat artefak yang dihasilkan dan sisa-sisa pengerjaannya. Keberadaan situs bengkel akan diperkuat lagi, apabila diperoleh bahan baku yang berupa bongkah-bongkah batu.

Bahan batuan yang digunakan sebagai alat, terdapat dua jenis bahan batuan yang sangat umum digunakan yaitu, rijang, kuarsa, dan jasper. Bahan baku chert atau lebih dikenal dengan rijang sudah lama dikenal sebagai bahan batu yang sering dipergunakan oleh manusia prasejarah hampir di seluruh periode maupun di berbagai tempat. Perlu diingat bahwa bahan chert mudah untuk di pangkas karena memiliki kandungan silika yang cukup tinggi sehingga mampu menghasilkan pecahan yang diinginkan dan memiliki tajaman yang tajam.

\section{SIMPULAN}

Situs-situs neolitik yang diteliti berjumlah 13 situs, tersebar di satu kecamatan, yaitu Kecamatan Bantarkalong. Pemilihan lokasi untuk aktivitas neolitik selain mempertimbangkan kenyamanan lingkungan, juga mempertimbangkan tersedianya sumber bahan baku. Lokasi situs menyediakan bahan jasper, rijang, dan kalsedon yang melimpah.Kegiatan neolitik yang dilakukan oleh masyarakat pendukung Ci Langla berkait dengan perbengkelan. Hal tersebut dikaitkan dengan ragam temuan yaitu tatal, serpih, calon beliung, dan beliung jadi. Meskipun demikian, pendukung situs-situs neolitik juga membuat alat-alat insendental seperti serut samping dari tatal yang ada.

\section{DAFTAR PUSTAKA}

Bordaz, J. (1970). Tools of the Old and New Stone Age. Natural History Press.

Ferdianto, A. (2013). Analisis Alat Litik dari Situs Karangnunggal, Kabupaten Tasikmalaya. Purbawidya, 2 No. 1.

Handini, R. (1999). Distribusi dan Karakter Situs-Situs Neolitik di Kecamatan Bantarkalong dan Karangnunggal, Tasikmalaya, Jawa Barat. Berkala Arkeologi 
Tahun XII, 2/Nov, 14-21.

Heekeren, H. (1972). The Stone Age of Indonesia. Verhandelingen KITLV LXI.

Laili, N. (2012). Jejak Aktivitas Manusia Pendukung Situs Pasirgadung Cineam, Tasikmalaya. In Arkeologi Ruang Lintas Waktu Sejak Prasejarah hingga Kolonial di Situs-Situs Jawa Barat dan Lampung (hal. 113-122). Alqa Print.

Laili, N. (2015). Laporan Penelitian Jejak Aktivitas Situs Neolitik di Situs Cipurut dan Gunungbatu, Bojongasih, Kab. Tasikmalaya.

Laili, N. (2016). Penempatan Situs-Situs Neolitik di Kawasan Karangnunggal, Tasikmalaya, Jawa Barat. Purbawidya, 5 No 2, 89-100.

Laili, N. (2014). Tinggalan Beliung di Jawa Barat Refleksi Jejak Jelajah Masyarakat Penutur Bahasa Austronesia. In H. dan E. Djafar (Ed.), Prosiding Seminar Nasional Arkeologi 2014 Kesatuan Dalam Keberagaman (hal. 113-122). Balai Arkeologi Bandung.

Oakley, K. P. (1972). Man the Tool Maker. Trustees of the British Museum National History.

Said, Chaksana A.H dan Utomo, B. B. (2006). Pemukiman dalam Perspektif Arkeologi. In Triwurjani dkk (Ed.), Pemukiman di Indonesia Perspektif Arkeologi (hal. 1-15).

Simanjuntak, T. (1992). Neolitik di Indonesia: Neraca dan Perspektif Penelitian. Jurnal Arkeologi Indonesia, 1, 117-130.

Simanjuntak, T. dkk. (2008). Metode Penelitian Arkeologi. Pusat Penelitian dan Pengembangan Arkeologi Nasional.

Tanudirdjo, D. A. (1989). Ragam Metode Penelitian Arkeologi Dalam Skripsi Mahasiswa Arkeologi Universitas Gadjah Mada.

Tanudirdjo, D. A. (1991). Budaya Sampung Sebagai Budaya Transisi Masa Berburu dan Mengumpulkan Makanan Tingkat Lanjut Ke Masa Bercocok Tanam. Universitas Gadjah Mada. 